\title{
PENGARUH JARAK SILINDER, BAHAN BAKAR, DAN PERLAKUAN BIJI MENTE TERHADAP PROSENTASE CNSL
}

\author{
Amiruddin Abdullah ${ }^{1}$, Yohanes B. Yokasing ${ }^{2}$, Antonius Pangalinan ${ }^{3}$, \\ Jurusan Teknik Mesin, Politeknik Negeri Kupang ${ }^{1,2,3}$ \\ Jl. Adisucipto Penfui, Kupang, Nusa Tenggara Timur, Kode Pos 85148 \\ 1w2a2f@gmail.com¹, yohanesyokasing12@gmail.com², \\ antoniuspangalinan@yahoo.com ${ }^{3}$
}

\begin{abstract}
Abstrak
Kacang mente diperoleh dari biji jambu mente. Biji mente memiliki bentuk yang unik, kulit biji yang keras, dan mengandung cashew nut shell liquid (CNSL). CNSL bersifat racun, memiliki reaksi sangat kuat yang merusak dan melukai kulit bila tersentuh. Salah satu cara memudahkan pengupasan yakni membebaskan CNSL dan merapukan kulit biji mente dengan pembakaran. Sebelum dibakar biji mente mengalami perlakuan berupa dijemur, atau dikukus dan dijemur, dengan waktu yang direncanakan. Daun lontar dan batang bambu yang memiliki kemampuan nyala serta kecepatan pembakaran digunakan sebagai bahan bakar. Kecepatan pembakaran tergantung pada penguapan uap air dan zat-zat penguap tersebut tergantung dari besar kecilnya butir-butiran bahan bakar. Kajian dilakukan terhadap teknologi bakar kulit mente menggunakan 3 selinder dengan posisi horisontal menghasilkan prosentase CNSL tertinggi yakni 78,3 \%. Dengan menggunakan bahan bakar daun lontar, dengan perlakuan biji mente dijemur 8 jam, kondisi kacang mente berwarna putih dan utuh. Prosentase basah terendah $36,7 \%$ terjadi pada jarak silinder $30 \mathrm{~mm}$, dengan bahan bakar yang digunakan batang bambu, mendapat perlakuan kukus selama 13 menit, dijemur 24 jam, warna kacang ada yang putih, ada pula kuning. Pada prosentase yang lain selain dari prosentase $36,7 \%$ warna kacang mente tetap putih.
\end{abstract}

Kata Kunci; Biji mente, teknologi, prosentase CNSL.

\section{PENDAHULUAN}

Jambu mente memiliki produk utama berupa kacang mente. Kacang mente diperoleh dengan mengupas kulit biji mente. Biji mente memiliki bentuk yang unik, kulit biji yang keras, dan kulit juga mengandung cashew nut shell liquid (CNSL). CNSL bersifat racun, memiliki reaksi sangat kuat yang merusak bila bersentuhan bahan-bahan seperti kain, plastik, karet dan melukai bila mengenai kulit. Kendala dalam pengolahan ini kondisi biji dan kulit biji yang demikian menyebabkan orang engan mengolah kacang mente. Menurut Santoso B., 1996 mengatahkan bahwa, "Kacang mente terbungkus kulit mente yang keras dan tidak teratur serta adanya CNSL, yang bersifat racun" [1].
Hal ini diperparah, dengan tuntutan hasil kacang mente berkualitas, dimana masih utuh kacang yang dikupas dan memiliki warna tetap putih. Untuk itu dilakukan berbagai cara dalam mengolah biji mente untuk memenuhi tuntutan kacang berkualitas, diantaranya yakni perlakuan. Kendala yang dihadapi para pengelolah dan petani dalam mengupas mente dengan kacip tanpa perlakuan adalah rendahnya prosentase mente utuh yang diperoleh dan tercemarnya kacang mente oleh cairan CNSL [2]. Prosentase kacang mente utuh, yang dihasilkan oleh pengrajin rumah tangga, dan industri kecil sekitar $60-70 \%$ dengan mutu rendah [3].

Salah satu upaya mempermudah pengupasan yakni membebaskan CNSL dan merapuhkan kulit biji mente dengan pembakaran. Biji mente dibakar dengan 
menggunakan api, yang bersumber dari pembakaran bahan padat, cair atau gas. Bahan bakar padat konvensional yang memiliki kecepatan bakar tinggi seperti daun kelapa, daun lontar, dan batang bambu, banyak di Nusa Tenggara Timur (NTT). Kecepatan pembakaran, tergantung pada penguapan uap air dan zat-zat penguap tersebut tergantung dari besar kecilnya butir-butiran bahan bakar, akan berlangsung kira-kira selama lima menit [4].

Kesulitan pengupasan ini masih berlaku hingga sekarang, sehingga biji jambu mente dijual dalam bentuk (biji) gelondongan. Penjualan mente yang banyak dalam bentuk gelondong menyebabkan harga jual mente sering tidak menentu, dan cendrung merugikan petani. Menurut Felix Janggu, 2018, mewartakan bahwa, "Harga sekarang Rp. 18.000 sampai 19.000 per kilogram, tidak sampai $\mathrm{Rp}$. 20.000" [5].

Untuk itu dibutuhkan kajian pengolahan alternatif, seperti pembakaran yang didahului perlakuan berupa perendaman, pengukusan. Perlakuan ini berpeluang kacang mente semakin sedikit atau tidak bersentuhan CNSL, karena CNSL turut terbakar disaat pembakaran. Maka dilakukan kajian dengan judul, "Pengaruh Jarak Selinder, Ukuran Biji, Perlakuan, terhadap Prosentase CNSL pada Teknologi Bakar Mente Tiga Selinder".

\section{TINJAUAN PUSTAKA}

\section{Kacang Mente}

Kacang mente adalah produk dari biji jambu mente. Biji jambu mente memiliki bentuk biji yang unik dan dibungkus kulit biji yang keras. Kulit biji mente mengandung $C N S L$.

CNSL merupakan senyawa fenolat kompleks yang mengandung rantai cabang yang panjang dan sifatnya tidak jenuh. Minyak ini sangat korosif sehingga mampu melepuhkan kulit tangan. Sifat korosif ini dapat hilang jika mengalami perlakuan pemanasan karena akan terjadi dekarboksilasi yang mengubah asam anakardat yang sifatnya racun menjadi kardanol yang sifatnya lunak.

\section{Pengolahan Pasca Panen}

Lembar Informasi Pertanian (LIPTAN) LPTP Koya Barat, 1996 [6], menyajikan pengolahan biji mente, melalui tahapan-tahapan, sebagai berikut :

1. Pengeringan mente gelondong, dilakukan hingga kadar airnya mencapai $5 \%$, lama pengeringan 1-2 hari.

2. Penyimpanan mente gelondong, mente disimpan harus kering sempurna, yang belum kering masih ada CNSL akan mengakibatkan bijinya berwarna coklat. Penyimpanan bisa dengan cara curahan atau kemasan karung.

3. Pengupasan kulit mente gelondong, pengupasan dapat secara manual yaitu dengan cara pukulan, dengan alat kacip belah serta kacip ceklok.

4. Pengeringan biji, pengeringan dilakukan setelah biji dikupas, tujuannya mengurangi kadar air-nya hingga $3 \%$ dan untuk mempermudah pengupasan kulit ari mente (testa). Pengeringan bisa dengan sinar matahari atau dengan cara mekanis. Pengeringan dengan sinar matahari dilakukan hingga kulit arinya dapat dikelupas dengan tangan. Keuntungannya biji tidak gosong dan kualitas baik. Kelemahannya kadar airnya lebih 3\% biji sangat rapuh (mudah hancur), dengan cara mekanis dilakukan pada suhu optimum $70^{\circ} \mathrm{C}$, selama $4-8$ jam, kualitasnya baik dengan kadar air $\pm 3 \%$.

5. Pengupasan kulit biji mente (kulit ari), pengupasan kulit ari dilakukan setelah dikeringkan, pengupasan dapat secara manual, cara lain yang dilakukan oleh para petani yaitu proses gabungan antara pengorengan bersama- sama dengan pengupasan. Pada cara mekanis biji mente nya perlu dilembabkan kembali hingga mencapai kadar air 5\% (cara ini tidak dilakukan petani di daerah). 
6. Sortasi dan granding/pengelompokan tingkat dasar, sotir dan granding ialah keadaan, ukuran, serta warna, berdasarkan keadaan dapat dibedakan 6 golongan yaitu; biji utuh/whole; biji sedikit utuh/butts; biji belh/splits; remukan halus/ baby bits. Gelondong yang didapat berdasarkan warna yaitu biji putih/white kernels; biji agak putih/fancy; biji 1/2 gosong/ desserts; dan gosong/scarched. Beberapa standar menurut besar dan warna biji yang ada dalam perdagangan antara lain;

- White wholes (biji utuh seluruhnya, tiap ons berisi 100-200 biji, kerusakan akibat pegangkutan maksimal 10\% dan bebas kotoran)

- Butts (sebagian kecil bijinya sudah pecah); white splits (biji pecah/terbelah menjadi 2 bagian).

- Large white pieces (biji pecah dengan ukuran diatas $0,4-0,5$ $\mathrm{cm}$ )

- Scorched grades (standar yang paling rendah biji terbakar ringan)

7. Pengemasan, pengemasan perlu segera dilakukan karena biji-bijinya mudah sekali rusak. Kemasannya dapat berupa peti/kaleng, plastic kemas dalam keadaan tanpa udara.

\section{Kualitas Kacang mente}

Kacang mente berkualitas adalah kacang yang utuh dan berwarna putih. Untuk mendapatkan kacang mente berkualitas tentunya berasal dari:

1. Biji yang matang dipohon dan dilakukan pengeringan lanjutan pada kadar air yang disyaratkan,

2. Dikupas dengan benar (kacang tidak pecah dan tidak terkontaminasi dengan CNSL).

Kesulitan pengupasan biji mente untuk mendapatkan kacang mente karena terbungkus kulit yang keras, tidak teratur dan kulit biji mente mengandung minyak cashew nut shell liquid atau CNSL yang bersifat racun. Kendala yang dihadapi petani dalam pengupasan gelondong yakni rendahnya persentase kacang mente utuh yang diperoleh dan tercemar kacang mente oleh CNSL [2].

Persentase kacang mente utuh yang dihasilkan oleh perajin rumah tangga dan industri kecil sekitar 60-70\% dengan mutu rendah [3]. Percobaan pengukusan gelondong mente sebelum dikupas dengan kacip ceklok dilakukan untuk meningkatkan persentase kacang mente utuh dan kualitasnya serta rasa kacang tidak berubah.

\section{Teknik Pengolahan dan Perlakuan Lainnya di NTT}

Pada tahun 2005 [7], Wawan Lukman, melakukan kajian di Kab. Flores Timur, NTT. Dengan perlakuan gelodong biji berupa pengukusan gelondong mente sebelum dikupas dengan kacip ceklok dilakukan untuk meningkatkan prosentase kacang mente utuh dan kualitasnya serta rasa kacang tidak berubah. Pengukusan gelondong mente pada air mendidih selama beberapa menit dan dihamparkan satu malam menghasilkan prosentase kacang mente utuh lebih tinggi dibandingkan pola lama petani dengan tanpa perlakuan. Kacang mente juga tidak tercemar minyak laka karena kacang masih terbungkus.

Tabel 1. Rata-rata Jumlah Gelondong Mente, Presentase Kacang Utuh, Bobot Kacang, dan Lamanya Pengkacipan, FloresTimur, NTT [8].

\begin{tabular}{|c|c|c|c|c|c|c|}
\hline \multirow{2}{*}{$\begin{array}{c}\text { Dengan } \\
\text { Pengukusan/ } \\
\text { Ukuran gelondong }\end{array}$} & $\begin{array}{c}\text { Jumlah } \\
\text { Gelondong }\end{array}$ & \multicolumn{2}{|c|}{ Keutuhan Kacang (butiir) } & \multirow{2}{*}{$\begin{array}{c}\begin{array}{c}\text { Persentase } \\
\text { Kacang } \\
\text { Utuh }\end{array} \\
(\%) \\
\end{array}$} & \multirow{2}{*}{ 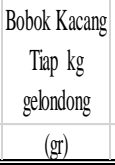 } & \multirow{2}{*}{$\begin{array}{c}\text { Lamanya } \\
\text { Pengkacipan } \\
\text { (menit) } \\
\end{array}$} \\
\hline & (butii) & Utuh & Pecah (kosong) & & & \\
\hline \multicolumn{7}{|l|}{ Dengan Pengukusan } \\
\hline Besar & 118 & 113,5 & 4,5 & 96,4 & 298,4 & 29 \\
\hline Sedang & 149,3 & 140,6 & 8,7 & 94,5 & 301,5 & 35 \\
\hline Kecil & 188,5 & 176,5 & 12,0 & 93,9 & 332,5 & 35 \\
\hline Rata-rata & 151,9 & 143,5 & 8,4 & 94,9 & 310,8 & 33 \\
\hline \multicolumn{7}{|l|}{ Tanpa Pengukusan } \\
\hline Besar & 132 & 117 & 15 & 88,9 & 294,2 & 42,5 \\
\hline Sedang & 164,5 & 137,1 & 27,4 & 84,1 & 290 & 56 \\
\hline Kecil & 208,0 & 149 & 59 & 71,6 & 300 & 55 \\
\hline Rata-rata & 168,2 & 134,4 & 33,8 & 81,5 & 294,7 & 18,2 \\
\hline Selisin & 16,5 & 9,1 & 25,4 & 13,4 & 16,1 & 18,2 \\
\hline
\end{tabular}




\section{Kemampuan Nyala dari Bahan Bakar Kayu}

Prinsip pembakaran bahan bakar sejatinya adalah reaksi kimia bahan bakar dengan oksigen (O). Kebanyakan bahan bakar mengandung unsur karbon (C), Hidrogen $(\mathrm{H})$ dan Belerang (S). Akan tetapi yang memiliki kontribusi yang penting terhadap energi yang dilepaskan adalah $\mathrm{C}$ dan H. Masing-masing bahan bakar mempunyai kandungan unsur $\mathrm{C}$ dan $\mathrm{H}$ yang berbeda-beda. Proses pembakaran terdiri atas dua jenis yaitu pembakaran sempurna (complete combustion) dan pembakaran tidak sempurna (incomplete combustion). Pembakaran sempurna terjadi apabila seluruh unsur $\mathrm{C}$ yang bereaksi dengan oksigen hanya akan menghasilkan $\mathrm{CO}_{2}$, seluruh unsur $\mathrm{H}$ menghasilkan $\mathrm{H}_{2} \mathrm{O}$ dan seluruh unsur $\mathrm{S}$ menghasilkan $\mathrm{SO}_{2}$.

Sedangkan pembakaran tak sempurna terjadi apabila seluruh unsur C yang bereaksi dengan oksigen seluruhnya tidak menjadi gas $\mathrm{CO}_{2}$. Keberadaan $\mathrm{CO}$ pada hasil pembakaran menunjukkan bahwa pembakaran berlangsung tidak sempurna. Faktor-faktor yang mempengaruhi pembakaran bahan bakar padat, antara lain:

1. Ukuran partikel, partikel yang lebih kecil ukuranya akan cepat terbakar.

2. Kecepatan aliran udara, laju pembakaran akan naik dengan adanya kenaikan kecepatan aliran udara dan kenaikan temperatur.

3. Jenis bahan bakar, jenis bahan bakar akan menentukan karakteristik bahan bakar. Karakteristik tersebut antara lain kandungan volatile matter dan kandungan moisture.

4. Temperatur udara pembakaran, kenaikan temperatur pambakaran menyebabkan semakin pendeknya waktu pembakaran. Sehingga menyebabkan laju pembakaran meningkat.

Kecepatan pembakaran, tergantung pada penguapan uap air dan zatzat penguap tersebut tergantung dari besar kecilnya butir-butiran bahan bakar, akan berlangsung kira-kira selama lima menit [4].

Kemampuan membakar pun bergantung pada jumlah kayu yang dipakai, laju pembakaran, kelembaban kayu, besar kecilnya kayu, serta tambahan bakar lainnya. Menurut T. Istirokhatun, et all, 2011 [9], mengatahkan bawah, "Hubungan kelembaban kayu terhadap konsentrasi PM 2,5 memiliki korelasi yang jauh dari 1 yaitu $\mathrm{R} 2=0,04$, hal ini dapat terjadi karena banyak faktor 10 sampel, seperti jumlah kayu yang dipakai, laju pembakaran, kelembaban kayu, besar kecilnya kayu, serta tambahan bakar lainnya.

\section{METODE PENELITIAN}

\section{Tempat dan Waktu}

Penelitian dilakukan di beberapa tempat desa Waiklibang, Lab. Teknologi Mekanik, dan Lab. Pengujian Material, Jurusan Teknik Mesin, Politeknik Negeri Kupang. Waktu pelaksanaan selama 11 bulan dalam tahun 2018 .

\section{Perancangan Teknologi}

Teknologi pembakaran biji mente, dirancang dengan pendekatan setiap komponen dengan pendekatan fungsional dan konstruksional. Komponen-komponen ini terbagi dalam 2 bagian konstruksi, yakni teknologi bakar kulit biji mente (TBKBM) Utama dan teknologi bakar kulit biji mente (TBKBM) Pendukung. TBKM utama terdiri dari, unit pengarah biji mente dan unit bahan bakar. Pada unit bakar bakar terdapat selinder bahan bakar, letak selinder bahan bakar dapat diubah letak terhadap selinder biji mente.

\section{Pembuatan Teknologi}

Teknologi Bakar Kulit Biji Mente, dibuat di Lab. Perawatan dan Perbaikan Teknik Mesin, Politeknik Negeri Kupang. Teknologi ini dibuat dari bahan-bahan logam, dan menggunakan proses permesinan, diantaranya mesin bending, bubut, frais, cutting, welding dan lain-lain. 
Melakukan Kajian

Rancangan penelitian yang digunakan adalah rancangan acak kelompok (RAK):

$\mathrm{L}+\mathrm{A}+B+T=\mathrm{y}_{1}$ 1)

Keterangan:

L :Jarak Bahan Bakar dengan Biji Mente yang Dibakar,

A :Jenis Bahan bakar,

B :Jenis Perlakuan (B),

T :Waktu (T),

y :Prosentase CNSL pada kulit setelah dibakar

Jarak antara selinder biji mente dengan selinder bahan bakar luar dengan selinder bahan bakar lainnya tampak pada gambar 1.

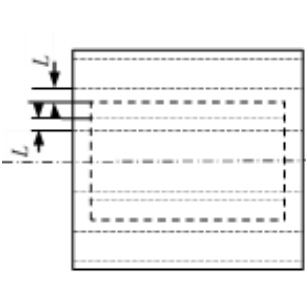

(a)

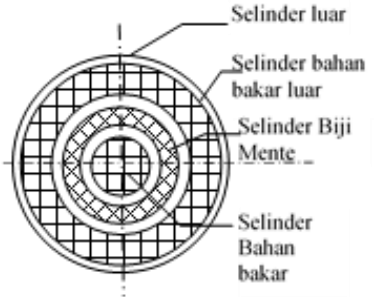

(b)
Gambar 1. Selinder Biji Mente (a) tampak depan, (b) tampak samping

Kemampuan membakar pun bergantung pada jumlah kayu yang dipakai, laju pembakaran, kelembaban kayu, besar kecilnya kayu, serta tambahan bakar lainnya

\section{Teknik Pengukuran CNSL}

Mempertimbangkan kualitas kacang mente, dibutuhkan teknologi pengolahan biji mente untuk mendapatkan kacang yang berkualitas, maka perancangan teknik pengukuran terhadap CNSL pada kulit mente hasil pembakaran dilakukan dengan "Pola pemetaan", tampak gambar pola pemeta. Pola pemeta dibuat dalam 3 ukuran, yang masing-masing diperuntukan untuk biji mente besar, sedang, dan kecil.

\begin{tabular}{|l|l|l|l|l|l|l|l|l|l|}
\hline 1 & 2 & 3 & 4 & 5 & 6 & 7 & 8 & 9 & 10 \\
\hline 11 & 12 & 13 & 14 & 15 & 16 & 17 & 18 & 19 & 20 \\
\hline
\end{tabular}

Gambar 2. Pola Pemetaan
Teknik pengukuran dengan visual, melihat basah atau tidaknya pada setiap bagian yang dipeta. Basah; kulit biji yang diamati basah (berminyak). Prosentase Basah atau CNSL = Jumlah pemeta kulit berminyak CNSL atau basah dibagi $20 \mathrm{kali}$ 100 prosentase.

\section{Prosedur melakukan kajian}

Prosedur kajian akan dilakukan dengan tahapan, sebagai berikut; biji mente disortir, ada biji mente yang langsung dijemur sesuai variabel yang dirancang dan ada biji mente dikukus sesuai variabel yang dirancang dan dijemur, biji mente dibakar, pengupasan, pemetaan kulit biji; pengamatan visual terhadap kulit, dan kacang mente berupa warna dan utuh tidaknya; pendataan

\section{HASIL DAN PEMBAHASAN}

Kajian Sebelumnya, Teknologi Bakar Kulit Biji Mente, memiliki 3 Selinder Ruang Vertikal yang memiliki 3 Selinder Ruang Vertikal

Kajian sebelumnya, Amiruddin Abdullah, et all 2017" [10], menghasilkan, "Untuk bahan bakar bambu prosentase basah atau CNSL yang ada pada kulitnya sebanyak 56\%, dibandingkan dengan bahan bakar daun lontar 63,4\%. Sedangkan biji mente yang mendapatkan perlakuan, berupa penjemuran, CNSL tersedikit terdapat pada penjemuran 3 hari yakni 65,6 $\%$, dibandingkan hari pertama dan kedua. Perlakuan pengukusan 13 menit dengan penjemuran 2 hari CNSL yang belum terbebaskan hanya $40 \%$, jika dibandingan lamanya pengukusan 11 menit dan 9 menit. Kacang mente berwarna kuning terjadi pada pengukusan selam 13 menit dan penjemuran 2 hari, dan semua utuh".

Kajian Sekarang (2018), Teknologi Bakar Kulit Biji Mente (TBKBM), memiliki 3 Selinder Ruang Berposisi Horisontal.

Variabel yang dikaji yakni jarak (bahan bakar terhadap biji menteh), bahan bakar, perlakuan, terhadap prosentase CNSL yang ada pada kulit kacang mente 
dan mengamati warna dan utuh tidaknya kacang mente. Temperatur dan lama pengukusan masing-masing $100^{\circ} \mathrm{C}$, dan selama 9 menit, 11 menit, dan 13 menit. Lama penjemuran 8 jam, 16 jam dan 24 jam. Waktu yang dibutuhkan untuk membakar yakni 120 menit.

\section{Data kajian yang diperoleh}

\section{1) Jarak $20 \mathrm{~mm}$}

Tabel 2. Hasil Teknologi Bakar Kulit Biji Mente, untuk Jarak $20 \mathrm{~mm}$

\begin{tabular}{|c|c|c|c|c|c|}
\hline \multirow{3}{*}{ Bahan Bakar } & \multicolumn{2}{|c|}{ Perlakuan Biji Mente } & \multirow{3}{*}{$\begin{array}{c}\text { Presentase } \\
\text { CNSL pada Kulit } \\
(\%) \\
\end{array}$} & \multirow{2}{*}{\multicolumn{2}{|c|}{ Kacang Mete }} \\
\hline & \multirow{2}{*}{$\begin{array}{l}\text { Kukus } \\
\text { (menit) } \\
\end{array}$} & \multirow{2}{*}{$\begin{array}{l}\text { Jemur } \\
\text { (Jam) } \\
\end{array}$} & & & \\
\hline & & & & Warna & Utuh/Pecah \\
\hline \multirow[t]{12}{*}{ Daun Lontar } & - & 8 & 78,3 & putih & utuh \\
\hline & - & 16 & 68,3 & putih & utuh \\
\hline & - & 24 & 61,7 & putih & utuh \\
\hline & 9 & 8 & 58,3 & putih & utuh \\
\hline & 11 & 8 & 58,3 & putih & utuh \\
\hline & 13 & 8 & 55 & puth & utuh \\
\hline & 9 & 16 & 51,7 & puth & utuh \\
\hline & 11 & 16 & 48,3 & putih & utuh \\
\hline & 13 & 16 & 46,7 & putih & utuh \\
\hline & 9 & 24 & 45,0 & putih & utuh \\
\hline & 11 & 24 & 45,0 & putih & utuh \\
\hline & 13 & 24 & 43,3 & putih,kuning & utuh \\
\hline \multirow[t]{12}{*}{ Batang Bambu } & - & 8 & 71,7 & puth & utuh \\
\hline & - & 16 & 63,3 & putih & utuh \\
\hline & - & 24 & 61,7 & putih & utuh \\
\hline & 9 & 8 & 56,7 & putih & utuh \\
\hline & 11 & 8 & 56,7 & puth & utuh \\
\hline & 13 & 8 & 53,0 & puth & utuh \\
\hline & 9 & 16 & 50,0 & putih & utuh \\
\hline & 11 & 16 & 46,7 & putih & utuh \\
\hline & 13 & 16 & 45,0 & putih & utuh \\
\hline & 9 & 24 & 43,3 & puth & utuh \\
\hline & 11 & 24 & 43,3 & putih, kuning & utuh \\
\hline & 13 & 24 & 43,3 & putih & utuh \\
\hline
\end{tabular}

Untuk jarak bahan bakar dengan biji mente yang dibakar dengan jarak $30 \mathrm{~mm}$ prosentase basah tertinggi sebesar $66,7 \%$, perlakukan yang diberikan berupa penjemuran selama 8 jam, kacangnya berwarna putih, dan masih utuh. Prosentase basah terendah yakni 40,0\%, warna kacang putih, mendapat perlakuan berupa kukus 13 menit dan dijemur selama 24 jam.

Prosentase CNSL tertinggi yakni $78,3 \%$, terjadi pada bahan bakar daun lontar, dengan perlakuan biji mente dijemur 8 jam, kondisi kacang mente berwarna putih dan utuh, serta penjemuran selama 8 jam. Pada bahan bakar yang sama prosentase CNSL terendah yakni $43,3 \%$, dengan perlakuan pengukusan 13 menit, dijemur 24 jam, kondisi kacang mente yang dihasilkan ada yang kuning, ada pula putih, kacangnya utuh. Pada prosentase yang lebih tinggi dari 43,3\%, warna kacang mentenya masih putih.

Sedangkan pada bahan bakar bambu prosentase CNSL tertinggi yakni $71,7 \%$, perlakuan dijemur 8 jam, warna kacang masih putih dan utuh. Prosentase CNSL yang terrendah yakni $43,3 \%$, yang terdapat pada perlakukan pengkukusan 9 menit, 11 menit dan 13 menit, warna kacang ada yang kuning terjadi pada perlakuan kukus 11 menit, kacangnya utuh. Waktu penjemuran semua sama yakni 24 jam.

\section{2) Jarak $30 \mathrm{~mm}$}

Tabel 3. Rekapan Kinerja Teknologi Bakar Kulit Biji Mente, untuk Jarak 30 $\mathrm{mm}$

\begin{tabular}{|c|c|c|c|c|c|}
\hline \multirow{3}{*}{ Bahan Bakar } & \multicolumn{2}{|c|}{ Perlakuan Biji Mente } & \multirow{3}{*}{$\begin{array}{l}\begin{array}{l}\text { Presentase CNSL } \\
\text { pada Kulit Mente }\end{array} \\
(\%)\end{array}$} & \multirow{2}{*}{\multicolumn{2}{|c|}{ Kacang Mete }} \\
\hline & Kukus & Jemur & & & \\
\hline & (menit) & (Jam) & & Warna & Utuh/Pecah \\
\hline \multirow[t]{12}{*}{ Daun Lontar } & - & 8 & (66,7 & putih & Utuh \\
\hline & - & 16 & 66,7 & putih & utuh \\
\hline & - & 24 & 63,3 & putih & utuh \\
\hline & 9 & 8 & 56,7 & putih & utuh \\
\hline & 11 & 8 & 55,0 & putih & utuh \\
\hline & 13 & 8 & 53,0 & putih & utuh \\
\hline & 9 & 16 & 50,0 & putih & utuh \\
\hline & 11 & 16 & 43,3 & putih & utuh \\
\hline & 13 & 16 & 45,0 & putih & utuh \\
\hline & 9 & 24 & 41,7 & putih & utuh \\
\hline & 11 & 24 & 41,7 & putih & utuh \\
\hline & 13 & 24 & 40,0 & putih & utuh \\
\hline \multirow[t]{12}{*}{ Batang Bambu } & - & 8 & 65,0 & putih & utuh \\
\hline & - & 16 & 65,0 & putih & utuh \\
\hline & - & 24 & 58,3 & putih & utuh \\
\hline & 9 & 8 & 53,3 & putih & utuh \\
\hline & 11 & 8 & 50,0 & putih & utuh \\
\hline & 13 & 8 & 51,7 & putih & utuh \\
\hline & 9 & 16 & 48,3 & putih & utuh \\
\hline & 11 & 16 & 48,3 & putih & utuh \\
\hline & 13 & 16 & 43,3 & putih & utuh \\
\hline & 9 & 24 & 41,7 & putih & utuh \\
\hline & 11 & 24 & 38,3 & putih & utuh \\
\hline & 13 & 24 & 36,7 & kuning & utuh \\
\hline
\end{tabular}

Sedangkan pada bahan bakar bambu prosentase basah tertinggi yakni sebesar $65,0 \%$, hanya mendapat perlakuan berupan penjemuran 8 jam, warna kacang putih dan masih utuh. Prosentase basah terendah yakni $36,7 \%$, mendapat perlakuan kukus selama 13 menit, dijemur 24 jam, warna kacang ada yang putih, ada pula kuning. Pada prosentase yang lain selain dari prosentase $36,7 \%$ warna kacang mente tetap putih. 


\section{KESIMPULAN}

Pada jarak $20 \mathrm{~mm}$, prosentase CNSL tertinggi yakni 78,3 \%, dengan bahan bakar de bahan bakar daun lontar, dengan perlakuan biji mente dijemur 8 jam, kondisi kacang mente berwarna putih dan utuh, serta penjemuran selama 8 jam. Prosentase CNSL terendah 43,3\%, terjadi pada bahan bakar daun lontar, dan juga pada batang bambu, perlakuan berupa pengukusan 13 menit, dijemur 24 jam, kondisi kacang mente yang dihasilkan ada yang kuning, ada pula putih, kacangnya utuh. Kondisi kacang berwarna kuning hanya terjadi pada prosentase CNSL 43,3 $\%$.

Jarak $30 \mathrm{~mm}$, prosentase basah tertinggi sebesar $66,7 \%$, bahan bakar daun lontar perlakukan berupa penjemuran selama 8 jam, kacangnya berwarna putih, dan masih utuh. Prosentase basah terendah $36,7 \%$, bahan bakar yang digunakan batang bambu, mendapat perlakuan kukus selama 13 menit, dijemur 24 jam, warna kacang ada yang putih, ada pula kuning. Pada prosentase yang lain selain dari prosentase $36,7 \%$ warna kacang mente tetap putih.

\section{Saran}

Menyadari bahwa jenis kemampuan bakar bahan bakar padat tergantung pada jenis dan volume bahan yang dibakar, perlu dilakukan variasi jarak terhadap volume bahan bakar yang lebih banyak lagi, agar mendapatkan rumusan yang tepat akan jarak tersebut. Perlu diperhatikan pergerakan biji mente yang dibakar, sehingga dapat terbakar merata.

\section{REFERENSI}

[1]. Santoso, B., "Membuat Pengupas Biji Mente", Tilik Desa IV (140): 5, 1996.

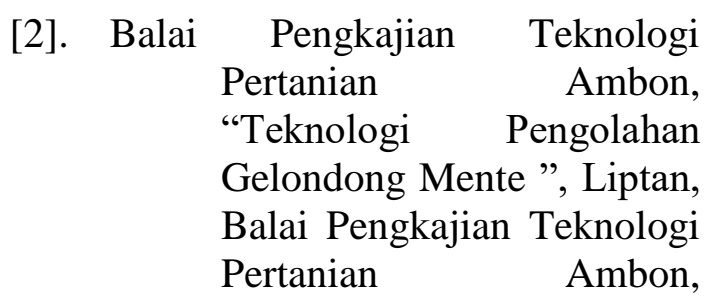

Nopember 1998.

[3]. Muljohardjo, J. M, "Teknologi dan Pengolahan Jambu Mente", Liberty, Yogyakarta, 1991.

[4]. Djokosetyardjo J. M., "Ketel Uap", Cetakan Kelima, Jakarta, PT. Pradya Paramita, 2003.

[5]. Janggu Felix, "Petani Mente Keluhkan Harga Mente Menurun", Pos Kupang, 13 Juli 2018, Kupang, 2018.

[6]. LPTP Koya Barat, "Pengolahan Biji Mente ", Lembar Informasi Pertanian (LIPTAN) LPTP Koya Barat, Irian Jaya, Loka Pengkajian Teknologi Pertanian, 1996.

[7]. Lukman Wawan, 2005, Teknik Perbaikan Kualitas Pengkacipan Buah Mente dengan Pengukusan, Buletin Teknik Pertanian Vol. 10, Nomor 1, 2005.

[8]. Buletin Teknik Pertanian, Vol. 10, No. 1, 2005.

[9]. Istirokhatun T., Wardhana Wisnu Irawan, Primely, "Analisa Pengaruh Kelembaban Kayu Terhadap Konsentrasi Pm 2,5 Dalam Dapur Berbahan Bakar Kayu Skala Replikasi dan Rumah Tangga", Jurnal Presipitasi, Vol. 8 No.1 Maret 2011, ISSN 1907-187X, 2011.

[10]. Yokasing, Y. B., Abdullah, A., \& Pangalinan, A. (2017). PENGELOMPOKAN DAN PERLAKUAN SERTA KEMAMPUAN BAKAR KULIT BIJI MENTE PADA TEKNOLOGI BAKAR KULIT BIJI MENTE. Turbo: Jurnal Program Studi Teknik Mesin, 6(2). 